\title{
Government and Opposition in Guyana
}

\author{
By Heiko Meinhardt
}

\section{Introduction}

It is the object of this study to describe and analyse the political development of Guyana since its independence in 1966. Guyana was the only British colony on the South American continent.

In 1964, the Afro-Guyanese Forbes Bumham and his party, the "People's National Congress" (PNC) won the elections against the Indian-Guyanese Cheddi Jagan and his ruling "People's Progressive Party" (PPP). Burnham took over the Office of Prime Minister. It can be assumed that the British government influenced the elections, because it probably had no interest in a victory by Jagan, who was an advocate of a dogmatic Marxist ideology.

Jagan had often stated that, if he won, he would rule Guyana in a radical left (communist) manner after its independence.

Although Burnham was a socialist, he was preferred to Jagan by the British because he was less extreme and more pragmatic than the PPP. London wanted to secure its interests in Guyana also after independence.

After Bumham had taken over the government, he began to consolidate his power because he had a fervent group of supporters, who backed his system. He was the leader of an autocratic regime.

Special importance shall also be put on the time after Burnham's death (August 1985) and President Desmond Hoyte's government which realised important economic changes in order to end the serious economic crisis, which he had inherited from his predecessor.

It is interesting that Hoyte, who has never introduced any democratic reforms, meets with unanimous approval for his economic changes from socialism to a free market system.

Today pragmatism in the economic policy seems more important for the Guyanese people than ideological points, also, racial political aspects seem less important than they did once. Originally, the PPP mainly represented the interests of the Indian-Guyanese people, whereas the PNC served the Afro-Guyanese people. But now it appears that the Indians accept the PNC rule only, because Hoyte is following the road to a capitalistic system. Jagan with his Marxist ideas would seem to be no altemative for the Indians. Taking these aspects into consideration, Hoyte's pragmatism, and realism, would seem to be the only possibility. Because the Indians are in the majority in Guyana, the PNC could probably win free and fair elections. Nevertheless, all elections held since independence appear to have been manipulated. 
Finally, the author analyses the political atmosphere from his own experiences during a research trip to Guyana in autumn 1989, and tries to evaluate the future of the Hoyte regime.

\section{The Political Development under Burnham (1966-1985)}

\section{The Political System}

In 1970, four years after independence from Great Britain, Guyana of ficially became the "Co-operative Republic of Guyana". Burnham introduced the economic system of "Cooperative Socialism". He pursued mainly two aims with this policy: Firstly, he wanted to separate Guyana from the former colonial power, Great Britain, and secondly, he wanted to expand his power and to put the PNC into a superior position, a fact Thomas 1 called the "proclamation of dictatorship".

In October 1980 the PNC, who held a two-thirds majority in the National Assembly - the parliament - instituted a new constitution. Burnham took over the position of the newly formed executive of President which is provided with far-reaching authority. According to the new constitution, the President is the Head of State, the supreme executive authority, and the Commander-in-Chief of the armed forces 2 . This means that he is the leader of the state, with virtually unrestricted power.

Guyana has a one-chamber parliament with 65 members, 53 elected in the National Elections and 10 indirectly elected in the Regional Elections (each of the 10 regional district governments elects one member to the National Assembly, according to Article 60 (3) of the constitution). The remaining two seats are drawn from representatives of the National Congress of Local Democratic Organs (Art. 60 (4)). National Elections must be held every 5 years (Art. $70(3)$ ).

Since 1964 there is absolute proportional representation, which also gives small parties a chance to win seats in parliament.

All political parties are allowed to participate in the elections.

The whole country forms one constituency. The decision which person on the alphabetic list of candidates receives a seat is made by the party leader ${ }^{3}$. Since 1985 , in the PNC, this is naturally Hoyte, and Jagan for the PPP.

On the regional level, Guyana is divided into 10 regions. The regional elections, which are held together with the national elections, (together they are called "General Elections") are

1 C. Thomes, The IMF-World Bank Group and the general crisis, in: Social and Economic Studies, Kingston, 1982, p. 20.

2 Constitution of Guyana, chapter IX, 89.

3 Dieter Nohlen, Wahlsysteme der Welt, Munich, 1978, p. 244 ff. 
important for the composition of the Regional Democratic Councils. The number of the seats in these councils depends on the number of the population living in the region.

\section{The Two Most Important Parties and Their Political Objections}

\section{a. The People's National Congress (PNC)}

The People's National Congress was founded in 1957, as a consequence of a serious disagreement between Jagan and Bumham of the political course of the party. This resulted in the People's Progressive Party separating into two wings. There were reasons for this development, officially, Bumham didn't want to go Jagan's way, which would have lead to a Soviet-orientated policy. He wanted to follow a more nationalistic orientated course. But two other aspects seem to be more important: The racial differences between Afro-Guyanese and Indians, and the personal ambitions of Burnham, who wanted more power.

Burnham presented himself as a moderate socialist, and kept his distance from Jagan's dogmatic Marxist ideas. Thus, there were two political mainstreams emerged in the preindependent Guyana.

As a result of the 1964 General Elections, Bumham took power and he became the first Prime Minister after independence, in 1966. For London he was the lesser evil.

Bumham took advantage of the permanent racial conflict between the Afro-Guyanese, and Indians, in order to consolidate his power. All the important positions in the state were occupied by his supporters - the Afro-Guyanese people. In this context, it should be remarked that the armed forces played a vital role in consolidating his power. The AfroGuyanese were in an overwhelming majority in the army.

Bumham pursued a socialist-orientated policy. He tried to cut all links with London, and in 1970 , he introduced the system of "Co-operative Socialism"4 in the hope to improve the relationships to the Socialist countries, however he always prevented Guyana from becoming a satellite state of the Soviet Union.

The nationalisation of foreign companies strained relations with the Western world, but Bumham didn't break the ties completely, as the negotiations between Guyana and the IMF (1978 and 1983) showed.

Bumham led the PNC with a powerful, and charismatic personality, and he was its undisputed leader. State, Georgetown, 1970. 


\section{b. The People's Progressive Party}

Jagan and his PPP failed to return to power after the absolute proportional representation system was introduced in 1964. Although the majority of the Indian people in Guyana amounts to about $50 \%$ of the population 5 . This is probably due to the following reasons. Firstly, it seems that the elections were heavily manipulated, and the PPP was restricted by (PNC-controlled) authorities, and secondly, Bumham built his power using a system of favouritism. However, Bumham didn't introduce a one-party-system, because he was frightend of racial conflicts and civil war.

The PPP played a losing game, but continued to criticise the PNC government, also Jagan never hesitated to attack Burnham personally.

The Marxist-orientated, basic principles of the PPP stayed unchanged. 6

Jagan mainly represented the downtrodden. However, if Jagan had come to power, he would almost certainly have consolidated his power in a similar way to Bumham.

The PPP, naturally, disagreed with all of the economic reforms that Burnham tried to introduce (improvement of the relations with capitalist countries) in order to solve Guyana's economic problems.

The PPP, founded in 1950, is the oldest political party in the country.

\section{The Legitimacy of the Burnham Regime}

It is difficult to evaluate the legitimacy of Bumham's regime, due to the above mentioned provisions he took to establish his power, such as favouritism and "Africanisation" of the armed forces, and electorial fraud. He ruled Guyana de facto as a dictator.

The Afro-Guyanese, who are in the minority (In 1980 about $30 \%$ of the population were Africans compared with about $50 \%$ Indians 7 ) participated in the PNC-regime. Therefore, it can be assumed that they could be counted as potential PNC-supporters.

The Indians favored the charismatic, and because of his fight against the British colonial power, ever popular Jagan and his PPP. They expected advantages with an Indian person coming to power. Jagan and his Marxist rhetoric was very popular with the very poor people, such as industrial workers, and small farmers.

With all this information available, the great victories of the PNC in the elections (i.e. 1980: $77,7 \%)^{8}$ are not very convincing.

5 Fischer-Weltalmanach, Frankfurt/Main, 1985, p. 299. The Afro-Guyanese people were only about $30 \%$ of the population.

6 People's Progressive Party: For Socialism in Guyana, Georgetown, 1989, p. 59.

7 Fischer-Weltalmanach, ibid., p. 337.

8 Keesing's Contemporary Archives, p. 31064. 
When the election results are seen as manipulated, it is impossible to value the democratic legitimacy of Bumham's regime. More important are two other factors of legitimacy: The loyal armed forces, and the probably loyal bureaucracy.

All rivals or enemies of Bumham, for example the popular figure Professor Walter Rodney, who wanted more democracy, were eliminated, because he was a danger for the political stability in Guyana.

Bumham did not ban the opposition, but restricted them in their work, especially before and during elections9.

His democratic legitimacy was, therefore probably not unjustly doubted by the PPP.

\section{The New Policy of Desmond Hoyte}

\section{The 1985 General Elections}

Only four months after Bumham's death Desmond Hoyte had to implement General Elections in December 1985. According to the constitution, General Elections must be held every five years 10 . Under the present electoral law 11 representatives for the 53 eligible seats in the National Assembly were elected, including the President, because every party appointed its leader for the presidency. The leader of the party that wins the majority of the seats in Parliament, is automatically the (indirectly) elected President.

Because of the system of absolute proportional representation small parties also have a chance to enter the National Assembly. There are no entrance barriers. The party has to win at least the number of votes which are necessary for one seat.

Together with the National Elections (to the Parliament) Regional Elections were held in order to elect the "Regional Democratic Councils", which are the regional administrations in the 10 regions. The number of the seats in these councils depends on the number of population living in the region 12.

According to Article 60 (3) of the Constitution every "Regional Democratic Council" elects an additional member of parliament. Two other seats are reserved for the "National Congress of Local Democratic Organs under Art. 60 (4) of the Constitution. Therefore, there are 65 seats in the National Assembly.

It was no surprise that the PNC achieved an overwhelming victory in both, the National and Regional Elections:

9 Frankfurter Allgemeine Zeitung, 17.12.1980 and: People's Progressive Party: Elections Crooked As Barbed Wire, Georgetown, June 1988, p. 3 ff., in which the opposition's view is described.

10 Constitution of Guyana, chapter VI, Article 70 (3).

11 Ibid., chapter V, Art.59 and 60.

12 Govemment of Guyana, An Analysis of the Presidential, National and Regional Elections of the Co-operative Republic of Guyana, Georgetown, (1986), p. 10. 
Results of the 1985 General Elections ${ }^{13}$

\begin{tabular}{|c|c|c|c|c|c|c|}
\hline \multirow[t]{2}{*}{ Party } & \multicolumn{2}{|c|}{ Votes } & \multicolumn{2}{|c|}{$\%$ of Votes Cast } & \multicolumn{2}{|c|}{ Seats } \\
\hline & 1980 & 1985 & 1980 & 1985 & 1980 & 1985 \\
\hline PNC & 312.988 & 228.718 & 77,7 & 78,5 & 41 & 42 \\
\hline PPP & 78.414 & 45.926 & 19,5 & 15,8 & 10 & 8 \\
\hline United Force & 11.612 & 9.810 & 2,9 & 3,4 & 2 & 2 \\
\hline $\left.\mathrm{WPA}^{*}\right) 14$ & - & 4.176 & - & 1,3 & - & 1 \\
\hline
\end{tabular}

*) The Working People's Alliance is a left wing party which opposes the PNC and United Force (UF).

The total number of votes cast was officially given as:

$\begin{array}{ll}\text { 198015: } & 406.265 \text { (from 493.550) }=81,7 \% \\ \text { 198516: } & 294.801 \text { (from 399.304) }=73,8 \%\end{array}$

Results of the Elections of the Regional Democratic Councils 17

\begin{tabular}{lccrr} 
Party & \multicolumn{2}{c}{ Votes } & \multicolumn{2}{c}{ Seats } \\
& 1980 & 1985 & 1980 & 1985 \\
PNC & 282.751 & 235.449 & 169 & 178 \\
PPP & 76.450 & 49.219 & 35 & 27 \\
UF & 4.334 & - & 1 & - \\
WPA14 & - & 3.642 & - & 0
\end{tabular}

These results imply a clear victory for the PNC under Hoyte. The PNC, although the number of people entitled to vote had decreased dramatically (which is due to the fact that the high number of Guyanese citizens who live outside the country were not allowed to vote in 1985) and the turnout was about $8 \%$ less than in 1980, defended its two-third majority, and also increased its percentage of the votes slightly. The smaller turnout could perhaps be a sign of a lack of interest of the people to the elections. Probably, people wanted to express their discontent with the PNC government in this way. This is considered in the economic crisis which was worse in 1985 compared with 1980.

13 Keesing's Contemporary Archives, p. 31064 and p. 34162.

14 The WPA had boycotted the 1980 General Elections.

15 R. Chandisingh, in: VRÜ vol. 15 (1982), p. 146.

16 Govemment of Guyana, An Analysis of the Presidential, National and Regional Elections of the Co-operative Republic of Guyana, Georgetown, (1986), p. 8.

17 Ibid., p. 10; for 1980 see Chandisingh, in: VRÜ vol. 15 (1982) p. 146. 
Remarkable is, that four out of the seven parties at the national elections entered Parliament. But the two most important opposition parties (PPP and WPA) achieved only 17,1\% of the votes cast ( 9 seats). The United Force is co-operating with the PNC.

All opposition parties (except the UF) declared the elections as "rigged". The PPP and WPA called the elections unacceptable on polling day, and withdrew their observers. Later on, however, they took their seats in the National Assembly. Although the racial aspect seems to be no longer important, this superior PNC victory is inexplainable without manipulation. The main accuser is of course the PPP. Not only did Jagan criticize the electoral law and the impediment of the work of the opposition but also "... the padding of the voter's lists with ficticious names, dead and underaged persons and the deletion of names of legitimate voters." 18

The most important demand of the PPP is that PPP-representatives should also be allowed to escort the ballot boxes to the central counting office or that the votes will be counted at the polling stations, under national and international observation. Up to now, it has been the practice that the armed forces collect the sealed ballot boxes, and deliver them to a counting center. The counting process is not public. However, in the 1985 General Elections it was de jure possible for the opposition to follow the ballot boxes to the counting centers, but the PPP refused to do so, probably in order to protest against irregularities (such as multivoting of PNC-sympathisers, intimidation of potential PPP-voters etc.) which seemed to be wide-spread. In contrast to 1980 , international observers and journalists were not permitted19.

Compared with the 1980 General Elections, there were very few changes, such as the abolition of overseas and postal voting, and the restrictions on the issues of proxy voting 20 . Especially the overseas vote was imputed as being manipulated by the PNC. But these changes could be described as cosmetic measures. If the govemment were really interested in free and fair elections, they would have allowed the public counting of the ballot under international observation. Therefore, a certain discrepancy between the official and the actual results seems to be more than likely.

In summing up, it can be stated that Hoyte did not break with Bumham's long tradition of manipulation in the elections. But indeed, this is not a surprise, because it must be seen that Hoyte was in power only weeks, before he had to hold elections. His inner-party authority and his authority as the President was not consolidated. The Bumham-supporters were dominant.

18 People's Progressive Party: What they said about Guyana elections, June 1989 (paper).

19 During the 1980 General Elections an intemational commission led by the British Lord Avebury observed the elections, which they described as "'... fraudulent in every aspect."' (see: Keesing's Contemporary Archives, p. 31064).

20 Election Commission: Electorial System in Guyana (paper, 1989). 


\section{The Economic Changes}

In contrast to the domestic policy Hoyte organized careful changes at first in his economic policy. These changes later became significant.

In the early 1970's Bumham introduced the "Co-operative Socialism", a variation of the socialistic planned economy. He tried to strengthen his ties with the Socialist countries but he never cut his relations with the Western world completely. This, theoretically, very functionable model did not work in practice. The consequence was a ruined economy. After Bumham finished a trip through various Eastem European countries (1985), he recognized that he could only overcome the serious economic crisis with the help of the rich capitalist countries and good relations with the IMF and World Bank because the socialist countries were neither willing nor able to support Guyana adequately.

Hoyte had taken over a financially ruined country without any perspectives. The Western world did not see him as a strong and ambitious President with charisma like Bumham but only as a temporary solution: They did "... not expect any fundamental economic changes ... to be quickly implemented, if at all. Indeed, the new president is regarded as a protege of Mr. Burnham's."21. But Hoyte would refute these fears.

Naturally, it was impossible to introduce a market-orientated economic system immediately, because Hoyte had to heed to the supporters of Burnham's socialist policy and, therefore, had to act very carefully so that he could retain, and indeed consolidate his power. An example of these considerations can be seen in the fact, that Viola Bumham, the widow of the President, still holds a position in Hoyte's cabinet. She is one of the four Vice Presidents responsible for education and social development 22 .

Hoyte stopped the anti-American rhetoric of Burnham, and improved relations with Washington. He also called off the embargo on wheat and flour imports from the USA, which was a very unpopular decision, made by his predecessor. Hoyte recognized that he could not solve the economic problems without pragmatism: "Ideology is a guide to action and not an instrument of inflexibility."' 23 .

The causes of the economic crisis are entirely domestic. Guyana is a potentially rich country with lots of raw materials, such as bauxit, aluminium, gold, diamonds and enough land for agriculture. Sugar and rice are the main agricultural export products.

Through smuggling and black market activities the state has lost a lot of income. Consequently, the govemment is unable to pay the salaries for the civil servants. The lower paid employees are susceptible to corruption. Another problem is that the majority of highly qualified people emigrate because they can eam much higher salaries overseas. Consequently, there is a lack of qualified workers, which are needed for a productive and functionable economy. Hoyte sees that there is a need for action: "If Socialism could have been

21 Kanute James, in: The Times, 14.8.1985.

22 Keesing's Contemporary Archives, p. 34162.

23 Financial Times, 18.3.1986. 
built by words ... we would have been the most advanced Socialists in the world. So let us forget the cant and prattling and let us get on with the work."'24. He recognized that there are positive links between a relatively strong, efficient economy and political stability. The so urgently needed foreign investors could only be interested in Guyana when the government wins back the trust of the international business world. Therefore, Hoyte had to go for a pragmatic, free enterprise-oriented way.

With this in mind, Hoyte expressed himself in many speeches, so also in August, 198925 when he explained the necessity of privatization and foreign investment. Indeed, he was careful when he stated. "... our party stands for self-reliance, human dignity, and the total emancipation of our people from the cultural and psychological shackles of the colonial past.", but then continued in his pragmatic way: "... the times demand that we eschew dogmatism, open our minds to fresh ideas, and adopt new ways of looking at things.".

It is his primary goal to win business confidence, the only chance to come out of the desolate economic situation.

Similarly to the former Minister of Manpower and Co-operatives and now PNC-Secretary Kenneth Denny explained the PNC position in an interview with the author 26 . In his opinion the PNC still saw its objective in the achievement of Socialism but the experiences they had in the past, and the serious economic crises, made it necessary to go a pragmatic way. There was no other alternative for Guyana to solve its crisis. Hoyte had to change the former PNC policy, because the Socialist countries could not support Guyana due to their own economic problems. But Denny stated that this was not a new course taken by Hoyte because Bumham had also seen that more pragmatism had been necessary (Bumham signed two IMF-agreements in 1978 and 1983). In Denny's view the economic reforms could easily be integrated in the ultimate need to achieve Socialism: However, Guyana must produce the goods, before it can develop in socialist manner 27.

Especially after the events which have happened in Eastern Europe, this changed policy would seem to be very convincing.

Hoyte and his PNC could hope for greater political support in his own country whether or not the reforms are able to improve the economic situation. The PPP with its dogmatic Marxist program would not be a good alternative to the present government. The voters would seem to recognize these facts.

25 A Nation at Work. Speech of President Hoyte to his party, Georgetown, 1989, see pp. 15-16.

26 The author made this interview in October 1989 when he visited Guyana on a private research trip.

27 Kenneth Denny in the above mentioned interview. 


\section{The Position of the People's Progressive Party under Jagan}

The PPP is the only serious political alternative to the well-organized PNC under Desmond Hoyte. Jagan's PPP has a long tradition in Guyana.

Since its foundation, the PPP has fought for a dogmatic Marxist-oriented political system in Guyana. After the PPP lost its power in 1964, the PPP became the biggest opposition party. Although both parties, the PPP and PNC, were left-wing organizations, Jagan was never a comfortable opponent of the govemment. He criticized, and still criticizes the PNC regime ruthlessly.

The PPP has its voters mainly in the poor and poorest social strata such as industrial workers and small farmers, who are naturally heavily affected by the economic crisis, for which the PNC is still held responsible. Their voters are mostly disadvantaged Indo-Guyanese people.

Certainly, Jagan's past solution for curing the economic ills is not convincing. He wants to realize a strict anti-capitalistic policy and still (at the end of 1989!) seeks to build up a Guyanese socialism, based on the theories of Marx and Lenin. His goals are stated in the PPP-program of 198928: "The PPP ... seeks to build a socialist society and ultimately to construct a communist society." and continued: "The PPP fights against reformism, pragmatism (and) opportunism ..."29. Also a violent fight for those aims are not excluded: "(The PPP) believes in mastering all forms and methods of struggle - peaceful and nonpeaceful ..."30. The party still wants to co-operate with the International Working Class Movement and believes in the victory of socialism: "Imperialism will be defeated and socialism will triumph."31.

The recently published PPP-program (winter 1989) be read as an essay on MarxistLeninism. The reality, namely the failure of socialism all over the world (Eastern Europe is a significant example, but also Third World countries such as Mocambique and Vietnam), seems to be ignored completely.

A bit more pragmatic, the PPP-secretary Gail Teixeira explained the position of her party in an interview with the author 32 .

In case of a victory in free and fair elections under intemational control the PPP would not establish a one-party-system, on the contrary she desired that PNC-officials would also be represented in the cabinet. The first priority was the rehabilitation of the economy. In contrast to the of ficial party statements, Teixeira explained that the PPP would not cut the ties with the Western world and its organizations (IMF, World Bank), however would never accept being dictated by them.

28 PPP-Program: For Socialism in Guyana, Georgetown, 1989.

29 Ibid., p. 58 and p. 60.

30 lbid., p. 61.

31 Ibid., p. 62.

32 The author interviewed Miss Gail Teixeira at Freedom House, the PPP Headquarters in Georgetown in October 1989. 
The PPP disagreed with Hoyte's privatization policy. Jagan stated: "Privatization and denationalisation are meant to reinforce dependent capitalism, which is the root of the problem of the vast majority of Third World underdeveloped countries." 33 . Therefore, the economic reform concept is quite unrealistic.

The political demands of the PPP are clear. At first free and fair elections must be held, which the party is certain they could win 34 . Jagan then would try to build a government with the participation of all important political and social forces 35 . Then the policy would probably be Marxist-Leninist orientated. The planned socialist economy would be introduced, in order to solve the economic crisis. Nevertheless, the experiences with this system are indeed not encouraging.

The fact that the PPP participate in the political system (i.e. in parliament) makes their attempt and intentions clear to provide an opposition, although the PPP has not accepted that the elections have been legal 36 .

The rising number of emigrants from Guyana, which is caused by the dire economic situation, is a serious problem for the PPP which means they loose large numbers of members and sympathizers 37 .

An interesting question is, what would the attitude of the Afro-Guyanese dominated army be towards a possible Jagan victory in the elections. Would they stand loyal to his government or would they take over (military coup) in order to secure their social interests? Miss Teixeira was unwilling to answer this question clearly.

To summarize, the PPP can be seen as a dogmatic Marxist-Leninist-orientated party which seems to have learned nothing from political realism.

\section{The Legitimacy of the Hoyte Regime}

The power of the Hoyte regime seems to be consolidated. This is not a surprise in consideration of the fact that Hoyte was able to take over a functioning system of favouritism and a working bureaucracy when he came into power in 1985. After he had won the elections in 1964 Burnham took every chance to establish his power. Towards this aim he built up a wide-spread and efficient system of support. Mainly the Afro-Guyanese got all the plum jobs in the administration, and the military leaders were also loyal PNC-members. Of

In: Thunder (PPP-paper), vol. 21, No. 2, 1989, p. 7.

Miss Teixeira expects $60 \%$.

See: PPP: National Unity for Democracy, Peace and Social Progress, Georgetown, August 1985, p. 67.

Ibid., p. 90.

Gail Teixeira in the above mentioned interview. 
course, Indians were also included in this system. Even some ministers of the PNC-cabinet were Indians 38 .

Hoyte continued with this policy. Although he introduced important changes in the economic course, as stated above, he has not realized any fundamental reforms of the political system such as free and fair elections or changes to democracy. This is probably explainable by his fear of loosing power. This is not unexpected, what leader would like to give up his power in order to introduce a democratic system? It cannot be expected that Hoyte would give up the amount of power which he holds according to the constitution (e.g. he has the right to dissolve parliament at any time he wants, see Art. 70 (2)). He does not have to give any reason.). Without doubt, Guyana can be called an authoritarian state.

Not even typical for such an authoritarian regime in the Third World is the fact that Guyana is not a one-party-state. There are opposition parties which can act and criticize relatively freely.

Of course, it is easier and more effective to control and observe a party like the PPP which is holding a courtship mainly with the Indians who are the majority of the population. Therefore, it is also easier to suppress the opposition. In the meantime, Guyana presents itself as a democratic country.

The PPP enjoys relative political freedom. The party can publish its own literature and sell it in its own bookshop (although they criticize the government heavily). Furthermore, party meetings can be held, and the PPP is also involved in parliamentary work. These low level activities cannot endanger the PNC-regime, because there are always legal (?) possibilities to restrict these activities, such as the reduction of the allocation of paper (which is stateowned) or mobilizing the bureaucracy, as Stone39 stated conceming elections: "'It is the easiest thing in the world to steal elections if all the institutions of government and especially the armed forces are manipulated to keep a party in power."'.

There are only two important newspapers in Guyana. The "Chronicle", a state-owned daily paper which publishes the government's opinion and the weekly "Stabroek News", which criticizes the PNC-policy mostly indirectly and carefully, so as not to lose their license. For example, it criticized favouritism, and explained that when there was no possibility of bringing the government down through elections and the consequences were discontent among the people 40 .

In conclusion, it can be said that the legitimacy of the Hoyte regime is based mainly on favouritism to his supporters, the armed forces and weak opposition, which seems unable to find a way out of the dire economic crisis. A democratic legitimacy (through fair elections) seems not to exist.

38 In 1984 e.g. the Vice President Ranji Chandisingh, the Minister of Energy and Mines, Harun Rashid and the Deputy Prime Minister M. Shahabuddeen. See: A.A. Fenty (ed.): 20 Years of Development, Georgetown, 1984, pp. 261-262.

39 Carl Stone in the Jamaica Gleaner, in: PPP: What say said about elections, Georgetown, June 1989.

40 Stabroek News, vol. 4, No. 78, 7.10,1989. 
The catastrophical economic situation is in Hoyte's view the most serious danger to the stability of his regime, as he stated in a speech in August 1989: "We have always had support, but (I) ... warn you, this support is not automatic and cannot be taken for granted. We can guarantee it only if the masses are satisfied ..."41.

But the popularity of the Hoyte regime seems to be better than the PNC may think. One reason for that could be that Jagan, with his dogmatic and unrealistic ideas, is not a desirable altemative to the pragmatism of Hoyte in the view of the people. This will be analyzed in the following section.

\section{The Political Atmosphere in Autumn 198942}

To gain an insight into the topical political atmosphere in Guyana, the author interviewed a number of Indians in order to ascertain their political views 43 .

The first question, which candidate would they prefer for the presidency, was clearly answered: Nearly all Indians of the working class prefered Jagan but the state-employed people, who are better educated, were undecided between the two parties. With regard to the economy all the people who were interviewed wanted a free-market-orientated system. Nobody wanted a socialist-orientated planned economy. These results are interesting, because there is an inconsistency between these answers, as the people who preferred Jagan, do not want a planned economy, for which the PPP is still fighting.

Regarding the question which aspect is most urgent, the recovery of the economy or democratic reforms, a large majority thought the economic aspect is much more important 44 .

The preeminence of the economic aspect seems to favour the free-market-orientated reforms of Hoyte. Although Hoyte's policy was criticized as being too slow and the political system as too undemocratic, the Indians that were interviewed, did not see Jagan as a good alternative. So answered nearly $90 \% 45$ of the people to the final question, would they prefer the PPP or PNC as the ruling party, that they would prefer a PNC-government, because Hoyte was, in their eyes, the lesser evil. This result deviated from this of the first

41 Desmond Hoyte: A Nation at Work (Speech), Georgetown, 1989, p. 14.

42 The author visited Guyana on a research trip in September/October 1989. During his visit, he had many (inofficial) interviews with Indo-Guyanese people, covering the different social strata. These interviews are not intended to be representative, they are only an insight to the political situation in Guyana.

4343 Indians were interviewed, 14 of which were members of the working-class (industrial workers and small farmers) and 29 were state-employees (such as medical doctors and engineers). AfroGuyanese people were not interviewed, because they are, due to the system of favouritism, in favour of the Hoyte regime. It is, e.g., easier for Afro-Guyanese persons to enter the public sector and coming in important and powerful positions.

44 Only 6 out of 43 asked persons thought that political reforms are most important.

45 Only 4 out of 43 interviewed persons favoured the PPP. 
question. This is probably due to the fact that racial aspects still play a role for the voters, especially for the working class members who suffer the most under the economic crisis mostly. However, the final results indicates that the racial aspect is not the dominant question for the Indians.

Naturally, these interviews are not representative but show that Jagan's chances to take office are very slight, even in a democratic system. Although this survey was not of an official nature and was a low representative value, it illustrates a general atmosphere, with which the author was confronted during his stay.

The economic aspects seem to be most important for the Indians. And the Indians seem to believe Hoyte to be more capable of realizing the economic reforms than Jagan. The dogmatic and stubbom position of the PPP seems no longer to be understood by the majority of voters, and is often seen as antiquated (especially because of the changes in the Soviet Union).

Consequently, the expectation of the PPP to win $60 \%$ of the votes in free and fair elections 46 seems to be unfounded. Also the serious economic crisis, for which the PNC is responsible, is nevertheless an advantage for the PPP.

There is a great optimism for the reforms, which Hoyte is going to introduce.

\section{The Perspectives for the Political Development}

As stated previously, Hoyte concentrated his reforms on economic aspects. He didn't see any need to change his autocratic style.

That he, like Burnham, manipulated the General Elections is no surprise, because he then was only in power a few weeks before the elections had to be held. The General Elections in December 1990 will be interesting, which according to the political atmosphere Hoyte would probably win, even if they were totally democratic. But it is unlikely that he could defend his two-third majority in parliament which is necessary for important changes in the constitution. Whether Hoyte will risk this, is another question.

It is more likely that Hoyte will continue his policy to try to bring Guyana out of its economic depression. But this could only be successful, if he turns away from socialism and cooperates with the economically strong Western world. In this case he will be successful with his reforms, and this would probably mean that Hoyte and his PNC would pass any examination of democratic legitimacy.

Only a few small parties which fight for a faster introduction of capitalism and democracy could be rivals, 47 but they are nearly all unknown, and (until now) they are not a serious danger for the regime.

46 As Gail Teixeira stated in the above mentioned interview.

47 For example: Paul Tennessee and his "Democratic Labour Movement", see: Guyana Forum, vol. 3, No. $1,1989$. 
So it seems to be likely that the PNC under Hoyte will also rule the fortune of Guyana in the future. However, an improvement of the economic situation is important for his political survival.

To what extent the Westem world could influence the political situation is a hypothetical question. But it is likely that the capitalist industrialized countries would favour a PNCgovemment.

Therefore, Hoyte and his party seem to be the future of Guyana, as they have leamt that economic changes and political stability are important. 


\section{Government and Opposition in Guyana}

\section{By Heiko Meinhardt}

The domestic political development in Guyana after independence in 1966 was mainly influenced by the three leaders of the two main political parties. The first national elections were held in 1964 and brought a strong majority for the People's National Congress (PNC) of the later first President Forbes Burnham. His party had separated from the People's Progressive Party (PPP) in 1957 after a serious disagreement between Burnham and Cheddi Jagan, the head of the PPP. It has stayed the strongest political force in parliament since.

The two parties stand for different political ideals. Whereas the PPP continues to fight for an orthodox Marxist-Leninist course in Guyanese politics, the PNC first followed a more moderate "Co-operative Socialism". Later, under Desmond Hoyte who became president in 1985 after Burnham's death, the PNC slowly tumed towards Western economic concepts, which may also have a positive effect in terms of a more democratic political structure.

The article also evaluates the relevance of the ethnic background of politicians and voters on the political scene. Last not least, the article gives a short insight into the opinions of Indian citizens on the basis of interviews with 43 Indians. The interviews are - of course not intended to be representative of the public opinion, rather to give an impression of opinions of a minority and a possible opposition. 